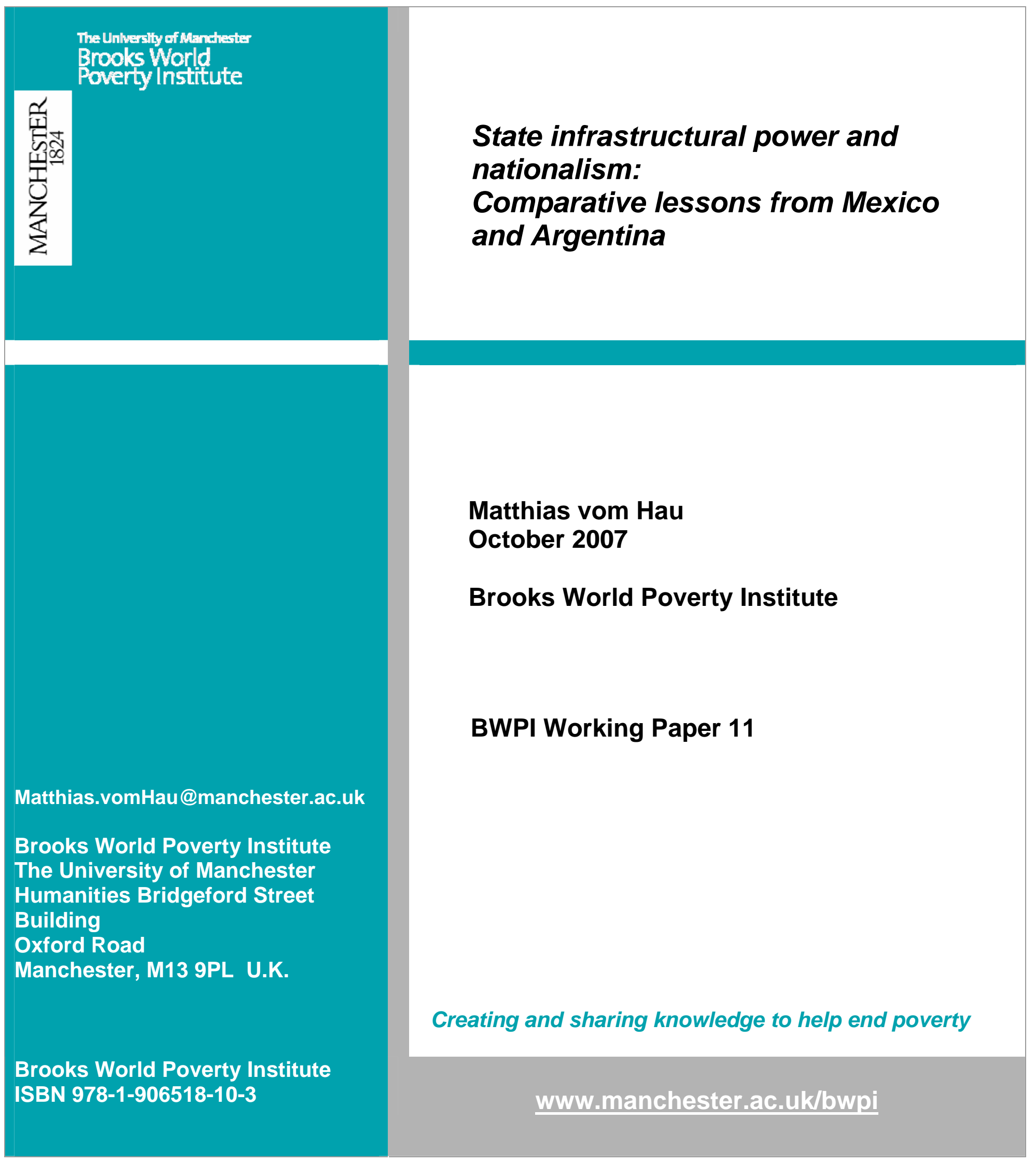




\begin{abstract}
This paper focuses on the nexus between state infrastructural power and legitimacy. A comparative case study of nationalism in mid-20th century Mexico and Argentina provides the basis for theorising the impact of state infrastructural power on transformations of official national ideology. Both countries experienced a transition from liberal to popular nationalism. Yet, the extent to which popular nationalism became a regular product of state organisations varied between the two cases, depending on the timing of state development. The temporal congruence between the expansion of state infrastructural power and ideological change, as exemplified by Mexico under Cárdenas, facilitated the full institutionalisation of the new official ideology, whereas a disjuncture between state development and ideological change, as exemplified by Argentina under Perón, inhibited such a comprehensive transformation of nationalism.
\end{abstract}

Keywords: Mexico, Argentina, nationalism, institutionalisation, education, schooling, state formation, state capacity, teachers

Matthias vom Hau is a Lewis-Gluckman Postdoctoral Research Fellow at the Brooks World Poverty Institute, The University of Manchester.

\title{
Acknowledgements
}

This research was supported by an IDRF fellowship from the Social Science Research Council (SSRC) and by the German Academic Exchange Service (DAAD). A previous version was presented at the 2007 Annual Meeting of the American Political Science Association in Chicago. I would like to thank Matthew Lange, Daniel Schensul, Dan Slater, Daniel Ziblatt for helpful comments. I also greatly benefited from the continued intellectual exchange with Hillel Soifer. 


\section{State infrastructural power and nationalism: Comparative lessons from Mexico and Argentina}

Michael Mann's $(1984 ; 1993)$ concept of state infrastructural power captures a crucial attribute of the state, its capacity to permeate social life and implement its decisions throughout the territory it claims to govern. State infrastructural power is based on a set of institutions that enable states to radiate out from the centre and penetrate society, most prominently administration, education, and the means of transportation and communication. It is also grounded in elite interest to employ these "logistical techniques," and in the social networks between central state authorities, those institutions, and local communities. Infrastructurally powerful states are thus able to draw upon the social control technologies necessary to name, register, tax, police, and educate their subjects, and they have the motivations and the local allies do so both in the capital and the farthest points of their territories.

Yet, even states endowed with the necessary technological, motivational, and institutional underpinnings may not be able to effectively exercise infrastructural power. For the central state to control and coordinate activities throughout society requires also some legitimacy in the eyes of societal actors. These supporting beliefs and emotional justifications of state power ease the presence of state organisations and facilitate local cooperation with non-state groups. In other words, the legitimation of state authority may reinforce the effects of the organisational forms and social relations constitutive of state infrastructural power, thereby expanding the capacity of states to implement their projects. ${ }^{1}$

This does not imply a one-way relationship. As a matter of fact, the legitimacy of the central state may equally be a product of infrastructural power. Infrastructurally powerful states marshal the organisational infrastructure and territorial presence necessary to actively intervene in the socialisation of their citizenry with the aim of instilling a belief in the legitimacy of state authority. Beyond enabling direct ideological and cultural work by state organisations, infrastructural power may also foster legitimacy indirectly. Just the presence of the state in daily life may foster a sense of emotional commitment to the collectivity the state claims to represent. Likewise, infrastructurally powerful states are more likely to deliver a wide variety of public goods the provision of which may in turn have a positive effect on the legitimacy of the state in the eyes of non-state groups.

This paper explores this nexus between infrastructural power and legitimacy based on an analysis of nationalism in mid- $20^{\text {th }}$ century Mexico and Argentina. In framing collectivities as sovereign, equal and inherently limited nations, and a state as their political embodiment, nationalism is critical for the construction of legitimate state authority. ${ }^{2}$ States employ nationalism as a discursive "toolkit" to draw the boundaries of national community and cultivate a sense of belonging among the resident population. As such, studying changes in the content of state-sponsored nationalism and the extent to which these discourses gain broader resonance provides a window on the role of state infrastructural power in the construction of legitimacy.

During the course of the twentieth century Mexico and Argentina experienced major transformations of official nationalism. In the late nineteenth century the two countries exhibited liberal nationalism as a dominant state ideology. These national discourses adopted a political-territorial understanding of the

\footnotetext{
${ }^{1}$ See Rueschemeyer (1986, chapter 4) for a more general perspective on the relationship between legitimacy and formal organisation.

${ }^{2}$ This point does not neglect that nationalism is equally important for the contestation of state power. Yet, the role of social movements in constructing national narratives and fashioning ideological transformations is beyond the scope of this paper. See Itzigsohn and vom Hau (2006) for a theoretical and empirical treatment of this issue.
} 
nation, imagined national unity as realised in the advancement of "civilization." Each also conceived of national history as driven by enlightened leaders and envisioned a small state and an export-oriented economy as the proper institutional structure to secure national progress. During well-defined periods in each of these countries, popular nationalism replaced the reigning liberal nationalism as official national ideology. These national discourses promoted a cultural understanding of the nation and depicted national unity as achieved through a homogeneous national identity. Popular classes appeared as protagonists of national history and a corporate state and inward-oriented economy as ideal underpinnings of national organisation.

Yet the extent to which popular nationalism replaced liberal nationalism varied among the two countries. In Mexico under the government of Cárdenas (1934-1940) popular nationalism became institutionalised as a regular product of the state cultural machinery, facilitating its translation into everyday forms of discourse. By contrast, in Argentina under Perón (1946-1955) state authorities did not manage to turn popular national discourses into hegemonic conceptions of Argentine identity and history that reinforce national identification. ${ }^{3}$

This paper seeks to explain these variations in the extent of ideological and cultural change. Why did the Cárdenas regime managed to turn popular nationalism into an implicit frame of reference, whereas the Perón regime-endowed with an infrastructurally more powerful state than Mexicofailed to secure the institutionalisation and broad societal diffusion of popular nationalism? To answer this question it is necessary to conceptualise the extent of transformations of nationalism more generally. I analyse the institutionalisation and dissemination of state-sponsored national ideologies as driven by patterns of state development. In particular, the extent to which popular nationalism became a regular product of state organisations depended on the relative timing of state development. The temporal congruence between the expansion of the state infrastructural power and ideological change facilitated the full institutionalisation of the new official ideology.

In both Mexico under Cárdenas and in Argentina under Perón, the establishment of ruling coalitions with subordinate sectors induced state elites to infuse official national discourses with popular ideas about national identity and history. In Mexico the incorporation of popular national discourses into state ideology unfolded simultaneously with a dramatic expansion of infrastructural power. By contrast, in Argentina an infrastructurally more powerful state did not manage to implement this change of nationalism. This was because Perón confronted an already established cultural machinery. In particular, well-trained and organised cultural producers exhibited the capacity to resist the institutionalisation of popular nationalism as a regular product of state organisations and prevented its ideological hegemony. Thus, more infrastructural power did not automatically translate into broader resonance of state-sponsored nationalism. It was the temporal order of state development vis-à-vis the change of nationalism that ultimately shaped the extent of ideological transformation.

To develop these arguments, the paper adopts a comparative-historical methodology (Mahoney and Rueschemeyer 2003). I anchor the macro-level argument about state development and nationalism and evaluate the cross-national patterns against more fine-grained evidence by choosing one institution-public education-as the main analytic window. For analysing nationalism as consciously articulated state ideology, I draw on a study of school textbooks, most importantly primary school

\footnotetext{
${ }^{3}$ National discourses are hegemonic if they obtain the status of broadly diffused narratives and framings. Defined that way, hegemony does not mean the consent of the governed, but refers to the presence of these discourses as "banal" reference points in daily life (Billig 1995; Gramsci 1971).
} 
textbooks on national history, literature, and civic education (vom Hau 2007). ${ }^{4}$ For tracing the translation of state ideologies into more implicit cultural scripts, I draw on interviews with teachers and periodicals from independent teacher associations. ${ }^{5}$

\section{State Infrastructural Power and Transformations of Nationalism}

This section develops a theoretical frame to explain variations in the ideological change of nationalism. Building on the idea that nationalism contributes to the legitimation of state authority, I present a conceptual model for tracing the extent to which official national discourses may change. The explanatory argument developed here focuses on the expansion of state infrastructural power and the relative timing thereof.

\section{Transformations of Nationalism}

I refer to nationalism as a form of discourse, a way of thinking and speaking about collectivities in terms of nations and national identities (Calhoun 1997). The basic underpinning of nationalism is the idea that a political unit is congruent with an imagined community of nationals. ${ }^{6}$ It charges certain normative principles, cognitive schemata, symbols, myths, and rituals with emotions and collective meaning and fuses them into specific reference points for the construction of national inclusion. These boundary markers are historical fabrications, but they may be experienced as primordial elements of collective life (Eisenstadt 1998). As such, nationalism constitutes a powerful tool for the cultivation of national identification, and ultimately, the legitimation of state power.

Modern states take an interest in both the content and the broader resonance of nationalism. States employ nationalism to represent themselves as an expression of a particular nation. How criteria of national belonging are conceived distinguishes the nation in question from others and delineates the rights and obligations of membership. Nationalism and its projections of the national community also help to frame state actions as following "national interest" and depicting the apparatus of rule as an extension of the national collectivity. By instilling a sense of national belonging, nationalism also shapes the interaction between central state authorities and non-state groups. The prevalence of state-sponsored national discourses in daily life affects the extraction of resources, the functioning of legal institutions, and the extent of societal responsiveness to state leaders.

In order to trace transformations of nationalism I draw a conceptual distinction between two distinct but interrelated discursive formations of nationalism. First, nationalism is a highly explicit and consciously articulated ideology put forward by the state in order to legitimate authority and achieve social control (Gellner 1983; Smith 1991). This form of nationalism is reflected in presidential

\footnotetext{
${ }^{4}$ In this larger project I use textbooks because public schools are arguably the major nationalising institution of the state during the $20^{\text {th }}$ century. State authorities put major efforts into regulating the content of these texts, for instance through special approval commissions. The textbook analysis starts with the implementation of obligatory public schooling during the late $19^{\text {th }}$ century, a period that witnessed the prevalence of liberal nationalism, and ends with the comprehensive (or contained) institutionalisation of popular nationalism. Thus, this study traces trajectories of nationalism as state ideology over substantial periods of time, from 1884 to 1955 in Argentina and from 1888 to 1960 in Mexico. In each country the study reviewed between 50 and 70 textbooks for these periods, collecting at least five publications per decade.

${ }^{5}$ For exploring teachers' role in this process I focused on the activities and outlooks of primary school teachers during the main transformative periods: the transitions towards popular nationalism under Cárdenas in Mexico (1934-1940) and Perón in Argentina (1946-1955).

${ }^{6}$ This definition provides a basis for distinguishing between nationalism and other forms of discourse involved in the legitimation of state power. For instance, agrarianism is distinct from nationalism because it evokes an imagined community of peasants rather than nationals.
} 
speeches, school textbooks, monuments, and public ceremonies. Second, nationalism is a cultural script with almost self-evident plausibility that provides a lens through which social reality is framed in daily habits and routines (Billig 1995; Lomnitz 2000). This form of nationalism is reflected in the cheering for one's national soccer team during World Cup, or taking the national framing of news for granted.

These two forms of nationalism are connected to each other in a dynamic process. State ideologies aim to become gradually translated into hegemonic cultural scripts. Cultural scripts help to propel the pervasiveness of states in the life-world of their resident populations. At the same time, cultural scripts enjoy relative autonomy from state control. On the basis of this conceptual model, I argue that transformations of nationalism entail the reorganisation of official ideas about the nation. $A$ comprehensive transformation of nationalism, the trajectory followed by Mexico under Cárdenas, is associated with the articulation of new or refurbished imageries of national identity and history in state ideologies, and the institutionalisation of state ideologies into cultural scripts. In a contained transformation, the trajectory followed by Argentina under Perón, the content of state ideologies changes, yet these refurbished official discourses do not achieve broader resonance as regular products of state organisations.

\section{State Infrastructural Power and the Institutionalisation of National Ideology}

States cannot simply adopt new forms of nationalism and turn them into broadly diffused frames of reference. For a comprehensive transformation of nationalism to take place, new forms of national ideology need to become broadly diffused as a regular product of state organisations, and need to be embedded in roles and organisations across the national territory (see Wuthnow 1989).

State infrastructural power is key to explain variations in transformations of nationalism. As infrastructurally powerful states are able to reach into society, they are expected to achieve the institutionalisation of new state-sponsored national ideologies as hegemonic cultural scripts. The presence of "logistical techniques" across national territory such as a largely literate population or road networks allow state authorities to broadly diffuse new forms of nationalism. Moreover, infrastructurally powerful states can draw on a variety of social control mechanisms at their disposal to routinise official national discourses in organisational practices, collective rituals and daily life interactions. Of particular importance are here educational and cultural state organisations such as schools or museums, yet also other state agencies such as tax offices and police stations play a role in the institutionalisation of new ideological forms. Finally, infrastructurally powerful states exhibit the capacity to provide even-handed social services, thereby also enhancing the diffusion of their ideological projects among the resident population.

This study follows a national capabilities approach (see Soifer 2008) and conceptualises SIP by focusing (1) on the institutions of penetration and (2) actors situated within these institutions and their relationship to central state authorities. The ability of states to radiate from the centre and reach their subjects can be assessed by examining the development and internal functioning of those institutions. $^{7}$

The dominant way to assess infrastructural power is to examine the ability of states to extract from society through the lens of taxation. Studying patterns of revenue collection reveals insights into the resources at the disposal of state elites to exercise control over society (Mann 1993; Lieberman 2003). Likewise, assessing the size and the territorial reach of the state administrative apparatus

\footnotetext{
${ }^{7}$ This is not to neglect other possible avenues of conceptualising SIP and its role in ideological change (see Soifer 2008).
} 
more generally provides the opportunity to gauge levels of infrastructural power. Examining the local presence of state agencies such as police stations or health clinics sheds light on the capacity to extend state control throughout the national territory. Moving beyond the organisational structure of states themselves, state infrastructural power can also be traced by considering "logistical techniques" that shape the implementation capacities of state organisations. Those include for instance literacy or road networks.

Yet, roads, tax offices, and health clinics are not directly involved in shaping the content of national ideologies. Cultural and educational state organisations therefore require analytical attention in their own right when assessing state infrastructural power (Gorski 2003; Loveman 2005). This "cultural machinery" of states includes the organisational facilities, resources, communicative networks, and rituals dedicated to regulating the production and diffusion of ideological products, and controlling cultural producers and their organisations (Berezin 1991; Wuthnow 1989). As a strategy to assess the reach of the state cultural machinery this paper focuses on different institutional domains engaged in the production and diffusion of ideological forms (e.g., public education) and corresponding state organisations (e.g., schools). While public schooling is certainly of critical importance, other relevant arenas for examining the ideological work of states include mass communication, art and entertainment, and public ceremonies and rituals.

State infrastructural power varies with respect to the scope of the cultural machinery. For instance, an extensive network of public primary schools facilitates the broader circulation of state-sponsored ideological products. Reach is also a function of the amount of resources dedicated to an institutional domain of the cultural machinery. For example, monetary patronage and subsidies for national history institutes facilitate control over these organisations and their intellectual production. And finally, the cultural machinery of states varies in their capacity to engage in the regulation of ideological products. For instance, state authorities issue detailed guidelines defining the content of school textbooks or engage in the explicit promotion or censorship of art works or literature.

Another defining feature of state infrastructural power conceptualised at the national level is the relationship between state authorities and the institutions of penetration. Even if those institutions exhibit the size, scope and resources necessary to reach into society, infrastructural power may be limited because of the lack of allies among the principal actors within those institutions. In the context of this study the relationship between state elites and the cultural producers situated within the ideological infrastructure is of critical importance for the ability to fashion transformations of nationalism. Strained relations may foster the opposition of cultural producers and thereby inhibit the production and diffusion of ideological forms from "within the state." For instance, public school teachers may resist the ideological orientation of the official curriculum designed and implemented by educational officials and employ a variety of strategies to subvert its content in the classroom. Thus, infrastructural power is not exclusively a function of the reach of state organisations and complementary "logistical techniques," it is also based on the training and outlook of principal actors within those institutions of penetration and their alignments and contestations with central state authorities.

Finally, ideas about relative timing and historical sequence are useful for assessing state infrastructural power (Ertman 1997; Rueschemeyer 1973; see also Pierson 2004). I argue that an already established cultural machinery makes it more difficult for state elites to convert a new national ideology into a regular product of state organisations. Analogously, the extent of ideological transformation remains limited when state sponsored national discourses change in the absence of any significant infrastructural power. In such a case, neither old nor new forms of official nationalism 
are regular products of the state cultural machinery. ${ }^{8}$ By contrast, the diffusion of hegemonic cultural scripts is facilitated when the development of state infrastructural power is temporally congruent with discursive transformations. An established cultural machinery is marked by an already routinised production and diffusion of ideological forms, marshals a substantial geographical reach, and maintains cultural producers who were trained under the previous ideological regime. As such, an established cultural machinery is usually invested in the professional identity of these cultural producers, which in turn enhances their capacity to resist ideological changes proposed by executive authorities.

\section{From Conceptualisation to Measurement}

In order to assess how the reach of the state affects ideological change I focus on the resources of state agencies to disseminate and routinise official national discourses. In particular, I explore the institutions of social control that shape the ideological presence of states throughout the territory they claim to govern. The advantage of this measurement strategy is to avoid conflating the effects of state infrastructural power with the "logistical techniques" at the disposal of state authorities to fashion changes of nationalism.

The first measure employed to gauge general trends in state infrastructural power are the size and types of revenues extracted by the central state. Likewise, this study draws on information about the administrative involvement of state agencies in a variety of domains, most importantly the economy and social policy. The second set of measures seeks to assess the scope of the state cultural machinery. Those include public schooling expenditures, the number of public schools and teachers, as well as data on the regulation of curricular contents. To complement and crosscheck such a focus on education, this study also explores other institutional domains within the state cultural machinery, such as mass media and the arts. Finally, a third set of measures assesses the relationship between central state authorities and institutions of penetration, examining the activities and outlooks of teachers as key actors within the cultural machinery of the state.

\section{Liberal Nationalism}

During the late $19^{\text {th }}$ century Mexico and Argentina exhibited liberal nationalism as official national ideology. The broad-based institutionalisation of liberal national ideologies as cultural scripts, however, faced substantial limitations, as state infrastructural power remained limited.

This time period, often described as period of oligarchic domination (Centeno 2002; Halperín Donghi 1993), was marked by the consolidation of the central state. As such, Mexico and Argentina left the vicious circle of political turmoil and economic stagnation behind that characterised the immediate postcolonial era. Political centralisation was closely intertwined with economic expansion, largely driven by foreign investment, the production of agrarian exports, and incipient industries. ${ }^{9}$ The rural economy was dominated by large estates, the main beneficiaries of the commercialisation of agriculture. In the two countries oligarchic regimes grounded their political power in an alliance with a narrow elite of large landowners and industrialists, the main beneficiaries of the export boom. The majority of political offices went to members of these elites who ruled through a combination of clientilism, electoral manipulations, and repression (Botana 1998; Knight 2002; Oszlak 1982).

\footnotetext{
${ }^{8}$ This latter trajectory is not explored empirically in this essay, yet it constitutes a logical possibility.

${ }^{9}$ In Argentina this economic bonanza was accompanied by the equally dramatic demographic reorganisation of society based on massive European immigration.
} 
Mexican and Argentinean state elites advanced liberal nationalism with the aim of legitimating the reigning oligarchic order (vom Hau 2007). Official national ideologies depicted the respective constitutional framework, political territory, and civic rituals as the main sources of national belonging. Accounts of national history further reinforced this political understanding of national identity. Descriptions of the postcolonial period focused on the gradual formation of a binding legal and political order, while systematically downplaying the struggles and civil wars between regional strongmen and political elites that characterised these countries during the early $19^{\text {th }}$ century.

At the same time, liberal national discourses were deeply infused with Comtean ideas about biologically determined social hierarchies and engineered progress from above. Liberal nationalism advocated the spread of "civilization"-a category associated with whiteness, economic modernisation, and an urban and cosmopolitan European culture-as the main vehicle for overcoming the ethno racial and political divisions that marked these three countries. "Civilization" had to be protected and systematically expanded vis-à-vis "barbarism." The indigenous population living within the boundaries of the national territory appeared as the most prominent "uncivilized" other, posing a threat to the national fabric. Liberal national discourses envisioned enlightened elites as protagonists of national history. Official representations of national history were organised around major political leaders, whether Aztec rulers, colonial viceroys, or post-independence presidents. Thus, national discourses in late $19^{\text {th }}$ century Mexico and Argentina combined Enlightenment ideals of citizenship and popular sovereignty with highly exclusionary and hierarchical imageries of national membership.

State infrastructural power remained limited in oligarchic Mexico and Argentina. The reach and implementation capacities of the state cultural machinery were low, inhibiting the translation of liberal nationalism into hegemonic national discourses. Oligarchic state elites constructed and expanded cultural and educational organisations with the explicit aim to "nationalise" the resident population. Yet, especially in Mexico the development of a national education system was more an official project than a social reality. The effects of public schooling were small, even after two decades of substantially increased government spending. Low levels of school attendance and high illiteracy rates persisted. Moreover, little improvement was made in enhancing the quality of instruction. Teachers' salaries were low, leading to many absences and closing of schools, and the newly opened escuelas normales only trained a small faction of teachers (Knight 2002; Vaughan 1982).

When compared to Mexico, state ideological infrastructure in late $19^{\text {th }}$ century Argentina probably exhibited a more extensive reach (Oszlak 1982). The national school system was more advanced; both in terms of organisational development and financial resources, and other cultural state institutions exhibited a greater presence, facilitated by the comparatively well-developed communication facilities. At the same time, the majority of primary school teachers did not have a normal school diploma and received only a poor pay, while equipment and school buildings were often lacking (Bertoni 2001). Moreover, during the 1880s and 1890s state authorities allotted only six percent of the national budget to education, even less than in Mexico (Spalding 1972). Thus, even in Argentina state infrastructural power was modest at best.

\section{Transitions towards Popular Nationalism}

In Mexico and Argentina, transitions toward popular nationalism were shaped by changing political configurations. The incorporation of popular nationalism as official ideology was grounded in populist alliances and the increased political weight of subordinate forces. State authorities tended to include subordinate forces and popular national narratives when they sought to consolidate and legitimate state power. In Mexico during the 1920s and 1930s, the revolutionary struggles had left behind highly 
mobilised subordinate sectors that remained a powerful oppositional force throughout subsequent decades (Rivera Castro 1983; Meyer 1977). The Confederación Regional Obrera Mexicana (CROM) and the Communist Party subscribed to a class-based understanding of the nation and depicted peasants and workers as the protagonists of national history. During the same time period in Argentina, socialists and communists, the main representatives of organised labour, marshalled considerable ideological reach (Horowitz 1990; Saítta 2001). Their alternative national narratives reworked official story lines, portraying Spanish colonialism as the onset of imperial exploitation and depicting the gaucho as a wage labourer and symbol of subaltern revolutionary spirit.

Under Lazaro Cárdenas (1934-1940) popular nationalism replaced liberal nationalism as official national ideology in Mexico. This ideological change took off when a coalition between organised labour, peasants, and post revolutionary state elites consolidated (Hamilton 1982; Knight 2002; Meyer 2000). This shift in the domestic balance of power was accompanied by a change in language about the political community. Post revolutionary state elites selectively adopted themes and discursive patterns found in alternative popular narratives articulated by labour and peasant representatives. The reworked national ideology combined a cultural understanding of national identity with a focus on class. It also reinterpreted the mestizo nation as composed of peasants, workers, and smallholders and depicted these subordinate sectors as protagonists of national history. Their resistance reverberated throughout Mexican history and culminated in the Revolution, setting the stage for a more egalitarian, industrialised, and economically independent society.

A comparable ideological transformation unfolded in Peronist Argentina (1946-1955). During this period Juán Domingo Perón built a highly personalistic political movement grounded in a coalition with organised labour. Similar to Mexico under Cárdenas, this alliance entailed both the domestication of subordinate mobilisation and far-reaching material and symbolic concessions (Sigal 2002; Torre 1990). Official versions of national history assigned subordinate classes a critical role in shaping national destiny, contrasting the actions of the dispossessed "masses" with the ones of the "oligarchy." Perón and his wife Evita appeared as the embodiment of the nation, equating the political constituencies of the Peronist movement with the national community. While popular nationalism depicted Argentina as a crisol de razas of immigrants (the local version of the "melting pot"), it emphasised the Hispanic and Catholic roots of the nation.

In sum, popular nationalism eventually replaced liberal nationalism as official national ideology in the two countries during the mid- $20^{\text {th }}$ century. Yet the extent to which popular national discourses became institutionalised varied dramatically between Mexico and Argentina, depending on the relative timing of state development.

\section{State Development in Post revolutionary Mexico}

Mexico under Cárdenas witnessed a substantial expansion of state infrastructural power during the period of ideological transformation. In particular, the parallel institutional development of the state cultural machinery enabled the institutionalisation of popular national discourses as a regular product of state organisations. In a context of institutional innovation and growth, state elites more easily established new routines for the production and diffusion of ideological products and the training and control of cultural producers.

The Temporal Congruence of State Development 
From the late 1920s onwards Mexico finally overcame the legacies of institutional destruction and statelessness associated with the armed phase of the Mexican Revolution. Especially during the sexenio of Cárdenas (1934-1940) central state organisations extended their authority vis-à-vis regional and local forces, expanded their geographical reach, became more actively involved in the regulation of economy and society, and devoted substantial resources on developing state infrastructure. For instance, the organisational efforts involved the agrarian reform fostered the permanent presence of state agencies in rural areas. State elites also implemented rudimentary forms of social provision and installed anti-poverty initiatives (Knight 2002; Meyer 1977). The expansion of state infrastructural power was also reflected in public expenditures. While central government spending as percentage of GDP was around four per cent during the late Porfiriato, it almost doubled and reached eight per cent by 1940, and per capita spending of the central government almost tripled during the same time period (Knight 2002: 217-218).

The state cultural machinery followed these general trends of state development. During the 1930s the state cultural machinery in Mexico underwent a substantial expansion. Post revolutionary state elites viewed public education as the primary mechanism to pacify rebellious popular sectors and foster the integration of a heterogeneous society marked by civil war and violence. The Secretaria de Educación Pública (SEP) absorbed many of the municipal and state schools and complemented them with the construction of new federal schools. Per capita education spending (in 1950 pesos) increased from 6.9 pesos in 1930 to 11.3 pesos in 1940 (Wilkie 1970: 160-161), and the government dedicated between 12 and 14 percent of the national budget to public education (Knight 1994: 424). The number of rural primary school teachers working for the SEP was around 6,500 in 1930, and reached around 19,100 in 1942 (Vaughan 1997: 25). Increased resources and personnel in public education substantially altered school enrolment. By 1940, 70 percent of the children between six and ten attended primary schools, compared to a mere 30 percent in 1910 (Vaughan 1997: 25).

These patterns of public school expansion need to be treated with some caution. Many schools suffered from a shortage of resources and organisation. While training institutes celebrated teachers as the vanguard of the post revolutionary state, their pay remained poor and they often waited for month to receive their salary, with the result that especially among rural teacher turnover was rapid (Knight 1994). The actual attendance of public schools varied greatly across localities, largely depending on community response to them (Raby 1989; Vaughan 1997). Yet, even taking these caveats into account, the overall record indicates a substantial expansion of public schooling during the 1930s.

Mass communication was another domain that witnessed increased state involvement. Under Cárdenas radio became an authentic mass medium. Between 1930 and 1940, the number of radio sets increased from 100,000 to 450,000 . Cárdenas' major political speeches were transmitted nationwide, often reaching several million listeners. His government combined legal regulations with administrative measures and subsidies to extend control over radio broadcasting (Hayes 2000; Mejía Barquera 1989). Similar patterns of increased state intervention can be found in cinema. Under Cárdenas state elites became more involved in the regulation of movies by installing censorship mechanisms and expanding legislation that favoured nationally produced films. Moreover, the SEP sponsored around a dozen documentary or educational films a year that primarily focused on rural and indigenous life (García Riera 1998).

Public rituals were another mechanism involved in the diffusion of nationalism. Cárdenas was able to frequently secure mass attendance at civic ceremonies and political campaigns. The yearly celebrations of the grito for national independence began to draw more than a million participants to Mexico City's main square. Analogously, state elites introduced a number of new national holidays, such as the public commemoration of Zapata, which introduced the revolutionary into the established 
pantheon of national heroes (Knight 1994; Pérez Montfort 1994). Another crystallisation of statesponsored rituals were the public festivities celebrating the expropriation of Anglo-American oil companies in March 1938 (Knight 1992).

In sum, exploring post-revolutionary Mexican state development reveals a substantial increase of state infrastructural power. The general growth of institutions of penetration was intertwined with the institutional development of the state cultural machinery. Public education, mass communication, and civic rituals indicate a dramatic expansion of the cultural machinery.

\section{Teachers and the Cultural Machinery}

Micro-level evidence for domain of education complements the central finding of the macro analysis, that the simultaneous state development, especially of the cultural machinery, facilitated a comprehensive transformation of nationalism in Mexico. ${ }^{10}$

Mexican teachers during the 1930s were largely sympathetic to popular nationalism (see also Vaughan 1997). The majority of teachers followed official national discourses in portraying subordinate sectors as the main forces in shaping Mexico's fate. Teachers also embraced the materialist perspective on Mexican history found in popular nationalism. They viewed economic factors and the conflict between different social classes as decisive for Mexico's historical trajectory. Spanish colonialism was ultimately motivated by the strife for profits from precious metals, land, and a dependent labour force. Before the onset of colonial rule "the Mexicans were the owners of the land," while subsequently "large Spanish landowners, together with the clergy, took away the lands of these people." 11 Such an assessment of Mexico's economic situation during the colonial period blends into another major theme in teachers' visions of national history, the focus on imperialism. The majority of interviewees suggested that during the postcolonial period foreign domination over the nation's resources did not cease and Mexico developed in a situation of dependency.

Teachers' support of popular nationalism was likely to shape their teaching. While this study does not have the data necessary to directly show what contents teachers actually taught in Mexico during the 1930s, the evidence available strongly suggest congruence between beliefs and practice. Teachers tended to embrace the new educational materials developed after 1935. Moreover, teachers did not show any significant opposition against attending frequent training institutes in which the dissemination of popular nationalism constituted an integral part of the curriculum. To the contrary, in self descriptions teachers stressed that they felt "unprepared" and emphasised that "we were somewhat improvised teachers,"12 welcoming these trainings as an effort to socialise a young and inexperienced teaching body into the profession. And even in cases where public school teachers complained about the top-down style of training institutes and lamented frequent supervision, they lacked the capacity to organise sustained opposition. Teacher unions only started to emerge during the 1930s and did not marshal the organisational infrastructure to effectively coordinate political activities and interest representation. ${ }^{13}$

In sum, public school teachers in Mexico under Cárdenas were inclined towards popular nationalism and largely embraced the ideological change found in educational materials and teacher trainings. Moreover, these cultural producers lacked the professional socialisation and level of organisation

\footnotetext{
${ }^{10}$ This section draws on interviews with teachers and periodicals from independent teacher associations, in combination relevant with secondary literature (vom Hau 2007).

${ }_{11}^{11}$ Public secondary school teacher (history), Mexico City, March 6, 1979

12 Public primary school teacher, Villahermosa, May 3, 1979

13 Public secondary school teacher (history), Mexico City, March 6, 1979
} 
which would have provided them with the capacity to successfully challenge Cardenas' nationalist project. Thus, the temporal congruence of the institutional development of state ideological infrastructure and ideological change shaped the institutionalisation and broad-based dissemination of popular nationalism.

\section{State Development in Peronist Argentina}

By contrast, in Peronist Argentina, state development was disjointed from transformations of nationalism. When Perón ascended to the presidency, the central state already exhibited substantial state infrastructural power, and institutions of social control achieved substantial reach. The state cultural machinery followed this general trend, and Peronist state elites confronted an already established cultural machinery. Well-trained and organised cultural producers exhibited the capacity to resist the institutionalisation of popular nationalism.

\section{State Infrastructural Power and an Established Cultural Machinery}

Argentina had already witnessed a dramatic expansion of state infrastructural power between the 1900 s and 1920s. State elites wrested power away from local authorities and state agencies became more involved in regulating market forces and pursued economic policies. In order to facilitate public sector intervention in the economy executive authorities also modified the internal organisation of the state apparatus, improving the professional training of civil servants, fostering the specialisation of state agencies, and installing more centralised control mechanisms (Rock 2002; Romero 2001).

Similar patterns can be observed for the state cultural machinery. In the domain of education state authorities expanded public schooling and teacher training facilities. Public expenditures for education increased both in absolute and relative terms. For instance, education expenditures almost quadrupled during the 1900s and 1910s, with the government earmarking three percent of the national budget for education in 1900, and 13 percent in 1914 (Spalding 1972: 52). During the same time period the number of public school teachers increased from around 8,600 to 21,500 (Gandulfo 1991: 314-315). As a result, already in 1932 around 69 percent of the relevant population was enrolled in primary schools. Throughout the 1930s, educational authorities further extended the reach of public schooling, especially in more remote rural areas. By 1942, the Ministry of Education oversaw around 13,200 public schools and 70,600 teachers (Secretaria de Estado de Cultura y Educación: 1966: 8-20). This expansion of the educational system went together with its internal organisation.

Educational authorities managed to centralise the administration of education, largely by enhancing the network of federal schools and bringing state and municipal schools under the control of the central state (Escudé 1990). During the same time period, teacher training across the various Escuelas Normales became more streamlined and uniformly organised (Puiggrós 1992). State elites tightened their grip on the regulation of curriculum content. Of particular importance was the appropriate "patriotic orientation" of the textbooks for the proper "argentinising" of the student body. State authorities also enhanced state control over mass communication. The Secretariat of Press and Information was founded to centralise the control and censorship of periodicals. Analogously, state authorities became more directly involved in radio broadcasting and movie making, establishing regulation, censorship, and subsidies for these new means of cultural production and mass communication (Escudé 1990). Finally, state support also went into the establishment of a professional soccer league, whose clubs, especially those from Buenos Aires, soon transcended local and regional loyalties and became powerful symbols of national identification (Alabarces 2002).

Teacher Resistance 
Micro-level evidence on teacher beliefs and practices provides additional support for the claim that prior state development inhibited a comprehensive transformation of nationalism in Argentina under Perón. The Peronist government did not manage to gain support among teachers, another constitutive element of the state cultural machinery. Executive authorities faced substantial resistance from these cultural producers situated "within the state," because an already consolidated education system had nurtured well-organised and professionally socialised teachers that objected Perón's ideological project.

Teachers active during the Peronist years largely opposed the new educational materials infused with of popular nationalism. ${ }^{14}$ Public school teachers voiced concerns about the glorification of the popular masses found in the new textbooks, noting that "mass politics and the theory of the dominant majority" would bear the danger of fostering "intolerance and coercion."15 Teacher opposition had real consequences for their classroom activities. During the Peronist years educational authorities increased the direct supervision of teachers, most importantly by sending inspectors for frequent surprise visits.

Yet, public teachers managed to circumvent or undermine the transmission of the official curriculum. For instance, teachers used the new textbooks, but only dedicated minimal classroom time to discuss their content. "We knew that someone could drop by and say something. So we did a short thing in passing [with the textbooks], but we didn't keep ourselves busy with it for long...so they [the students] forgot...this way we defended ourselves." ${ }^{16}$ Teacher resistance also focused on teacher training. Forms of opposition manifested themselves in frequent walkouts or refusals to actively participate in the training institutes.

A major factor in teacher opposition against popular nationalism was their already well-developed identity as members of a circumscribed status group. In contrast to Mexico under Cárdenas, where public school teachers welcomed more state micro management of the classroom, teachers in Argentina exhibited a strong sense of professional autonomy. They viewed the new educational policies under Perón as an intrusion into their profession. For instance, public school teachers saw the introduction of new textbooks as an offence against "the liberty to teach with the books we want [and pick] the topics we want...This caused the great majority of us teachers to become AntiPeronists." ${ }^{17}$ Thus, Argentinean public school teachers' resistance against popular nationalism was motivated by their own understanding of national identity and history, their opposition against the Peronist government, and a well-developed sense of professional autonomy. To an important extent, these motivations were shaped by the fact that the state cultural machinery was already in place by $1946 .{ }^{18}$ In contrast to Mexico's poorly paid and only recently recruited public school teachers, Argentine teachers had entered a well-established career path with a decent salary and clear guidelines for promotion, which positioned them squarely into the middle class. Multi-year training institutes set the standards for socialising teachers into the profession, their routines and curricula having been established under the previous ideological regime. Moreover, a high level of organisation contributed to teachers' capacity for opposition. Independent teacher unions engaged in information work and interest representation.

\footnotetext{
${ }^{14}$ For reconstructing the activities and outlooks of public school teachers under Perón I combined semi-structured interviews with a textual analysis of La Obra as a periodical written by teachers for teachers (vom Hau 2007).

${ }^{15}$ La Obra, No. 486, October 15, 1949, p. 58x

${ }_{17}^{16}$ Public primary school teacher, Buenos Aires, August 11, 2004

17 Secondary school teacher (history), Buenos Aires, August 25, 2004

${ }^{18}$ Accounts from secondary literature provide additional support for these findings, painting a similar picture of teacher opposition against Perón and popular nationalism (e.g., Cucuzza and Somoza 2001: Plotkin 2002), and the grounding of this resistance in their professional identity and middle class status (Bernetti and Puiggros 1994).
} 
In sum, well-trained and organised cultural producers exhibited the capacity to resist the institutionalisation of popular nationalism. As such, state institutional development before the adoption of a different national ideology impeded the translation of popular nationalism into cultural scripts.

\section{Transformations of Nationalism and their Legacies}

These contrasting trajectories of nationalism left important legacies in the two countries. In Mexico the comprehensive transformation under Cárdenas resulted in the installation of popular nationalism as hegemonic reference points in daily life. As such, popular national discourses became "uncoupled" from immediate political conflicts. During the subsequent decades, when the post revolutionary regime was increasingly characterised by political authoritarianism towards subordinate sectors, popular nationalism retained its hegemonic status as national ideology. By contrast, the contained transformations of nationalism in Argentina under Perón did not entail the hegemony of popular nationalism. Instead, popular national discourses remained fiercely contested and existed in a stalemate with the previously dominant forms of nationalism. After the fall of Perón in 1955, both Peronists and the anti-Peronists continued to represent themselves as the embodiment of the nation, translating conflicts over policy and office into contestations over national belonging and identity.

These different trajectories nationalism had major implications for lived experience. In Mexico, the hegemony of popular nationalism contributed to the durability of a one-party regime. In Argentina the contestedness of popular nationalism contributed to ideological polarisation and political instability. Patterns of nationalism also shaped citizenship regimes and redistributive policies in these countries. For instance, social services were more limited for those segments of the rural poor that did not fit the political identities of peasants and workers legitimised by popular nationalism (e.g., Collier and Collier 1991; Hamilton 1982; Plotkin 2002).

\section{Conclusion}

Mexico and Argentina experienced dramatic transformations of nationalism during the early and mid $20^{\text {th }}$ century. In both cases popular nationalism replaced liberal nationalism as an official national ideology. Yet, the extent of this ideological and cultural change varied substantially. In Mexico under Cárdenas, popular nationalism became institutionalised as a regular product of the state cultural machinery. By contrast, in Argentina under Perón the popular national ideology advanced by state elites did not turn into hegemonic points of reference.

This paper set out to explain this varying extent of ideological transformations in Mexico and Argentina by focusing on state infrastructural power. Findings indicate that the initial expectationthat infrastructurally more powerful states would be better able to successfully institutionalise and diffuse new forms of nationalism-requires some modification. The two case studies show that the expansion of state infrastructural power set the stage for the broader dissemination of popular nationalism when compared to the late $19^{\text {th }}$ century. The greater reach of the state apparatus through society, indicated by increased revenues and expanded state involvement in economy and social welfare, was a necessary condition for the diffusion of state-sponsored national ideologies. Yet, it was the timing of state institutional development that ultimately proved decisive for popular nationalism to become a regular product of cultural and pedagogical state organisations. More specifically, the temporal congruence between ideological change and the expansion of the state cultural machinery facilitated the institutionalisation of popular nationalism, whereas an already established cultural machinery impeded the broad-based dissemination of the new national ideology. 
In Mexico under Cárdenas the institutionalisation of popular nationalism was facilitated by the relative absence of a well established state ideological infrastructure in 1934. The dramatic expansion of cultural and pedagogical state organisations only began with Cárdenas. State authorities extended the reach of public schooling, increasingly intervened in the control of radio broadcasting, and enhanced the regulation of cultural politics. In turn, this temporal congruence between state development and ideological change furthered the translation of popular nationalism into cultural scripts.

In Argentina, an already established state ideological infrastructure posed severe limitations to the diffusion of popular nationalism. Professionally socialised cultural producers resisted executive authorities' attempts to rewrite the content of public education, and their professional autonomy and level of organisation provided them with the capacity to successfully challenge Perón's nationalist project. Their opposition closed a crucial channel for the translation of popular national ideology into hegemonic cultural scripts. Thus, the presence of an already established cultural machinery impeded the institutionalisation of popular nationalism, leading to constant contestation between national discourses that were not able to attain hegemony.

These findings point to an inherent tension in Mann's definition of state infrastructural power, while also highlighting a crucial strength of the concept, its relational character. The ability to penetrate society and exercise control throughout the national territory is not necessarily related to the ability of the state to implement policy. When assessing the resources at the disposal of central state elites it is evident that Peronist Argentina was an infrastructurally more powerful state than Mexico under Cárdenas. Yet, even with the capabilities to institutionalise popular nationalism in place, the opposition of well-organised teachers professionally socialised under the previous ideological regime impeded the diffusion of this new national ideology. Thus, SIP is inherently relational, constrained or facilitated not only by the relationships between state elites and non-state groups, but also by relationships between executive authorities and the actors situated within the radiating institutions of social control (see also Jacoby 2004).

By exploring the role of SIP in fashioning ideological and cultural change, this paper also speaks to the very definition of what the state is. This study finds support for Gorski's (2003) contention that state power is more than just "organised coercion" and the capacity to strip individuals from their resources. The dominant understanding of states as a "set of administrative, policing, and military organisations" (Skocpol 1979: 29) thus ignores important dimensions of the state apparatus. States equally include "pedagogical, corrective, and ideological organisations" (Gorski 2003: 165) engaged in fostering attachments, cognitive outlooks, and loyalties.

Finally, this paper also points to the centrality of time and temporal order in understanding the dynamics and impact of state action. The relative timing of state development was a crucial factor in explaining the extent of ideological and cultural change. This explanation builds on and supports more general arguments about the importance of timing for the analysis of the state (Ertman 1997; Rueschemeyer 1973). The argument about relative timing developed here thus might be applicable beyond the domains of culture and ideology. In particular, it might be extended to changes in social and economic policy, domains where institutional consolidation is marked by comparably high startup costs of physical and human capital and where already routinised forms of state involvement are likely to be resilient to rapid change. 


\section{References}

Alabarces, Pablo. 2002. Fútbol y patria: El fútbol y las narrativas de la nación en la Argentina. Buenos Aires: Prometeo libros.

Berezin, Mabel. 1991. "The Organization of Political Ideology: Culture, State, and Theater in Fascist Italy." American Sociological Review 56:639-651.

Bernetti, Jorge Luis and Adriana Puiggrós. 1993. Peronismo: Cultura política y educación (19451955). Buenos Aires: Galerna.

Bertoni, Lilia Ana. 2001. Patriotas, cosmopolitas y nacionalistas: La construcción de la nacionalidad argentina a fines del siglo XIX. Buenos Aires: Fondo de Cultura Económica.

Billig, Michael. 1995. Banal Nationalism. Thousand Oaks: Sage.

Botana, Natalio R. 1998. El orden conservador: La política argentina entre 1880 y 1916. Buenos Aires: Editorial Sudamericana.

Calhoun, Craig. 1997. Nationalism. Minneapolis: University of Minnesota Press.

Centeno, Miguel Angel. 2002. Blood and Debt: War and the Nation-State in Latin America. University Park, Pa.: Pennsylvania State University Press.

Collier, David, and Ruth Berins Collier. 1991. Shaping the Political Arena. Critical Junctures, the Labor Movement, and Regime Dynamics in Latin America. Princeton: Princeton University Press.

Cucuzza, Héctor, and Miguel Somoza. 2001. "Representaciones sociales en los libros escolares peronistas: una pedagogía para una nueva hegemonía." Pp. 209-258 in Los manuales escolares como fuente para la historia de la educación en América Latina, edited by Gabriela Ossenbach and Miguel Somoza. Madrid: Universidad Nacional de Educación a Distancia.

Eisenstadt, Shmuel N. 1998. "The Construction of Collective Identities in Latin America: Beyond the European Nation State Model." Pp. 245-263 in L. Roniger and M. Snajder (eds.) Constructing Collective Identities and Shaping Public Spheres. Brighton: Sussex Academic Press.

Ertman, Thomas. 1997. Birth of the Leviathan: Building States and Regimes in Medieval and Early Modern Europe. Cambridge: Cambridge University Press.

Escudé, Carlos. 1990. El fracaso del proyecto argentino: Educación e ideología. Buenos Aires: Tesis.

Gandulfo, Alberto. 1991. "La expansión del sistema escolar argentino: Informe estadístico." Pp. 309-361 in Sociedad civil y Estado en los orígenes del sistema educativo argentino, edited by Adriana Puiggrós. Buenos Aires: Galerna.

García Riera, Emilio. 1998. Breve historia del cine mexicano, 1897-1997. Mexico City: Ediciones Mapa and Conaculta.

Gellner, Ernest. 1983. Nations and Nationalism. London: Oxford University Press.

Gorski, Philip S. 2003. The Disciplinary Revolution: Calvinism and the Rise of the State in Early Modern Europe. Chicago. Chicago University Press.

Gramsci, Antonio. 1971. Selections from the Prison Notebooks, 1929-35. Edited and translated by Quintin Hoare and Geoffrey Nowell-Smith. New York: International Publishers.

Halperín Donghi, Tulio. 1993. The Contemporary History of Latin America. Durham, NC: Duke University Press. 
Hamilton, Nora. 1982. The Limits of State Autonomy: Post-revolutionary Mexico. Princeton, N.J.: Princeton University Press.

Hayes, Joy Elizabeth. 2000. Radio Nation: Communication, Popular Culture, and Nationalism in Mexico,1920-1950. Tucson: University of Arizona Press.

Horowitz, Joel. 1990. Argentine Unions, the State and the Rise of Perón. Berkeley: Institute of International Studies, University of California.

Itzigsohn, José, and Matthias vom Hau. "Unfinished Imagined Communities: States, Social Movements, and Nationalism in Latin America," Theory and Society 29 (April 2006), pp. 193-212

Jacoby, Tim. 2004. "Method, Narrative and Historiography in Michael Mann's Sociology of State Development." The Sociological Review 52: 404-421.

Knight, Alan. 1992. "The Peculiarities of Mexican History: Mexico Compared to Latin America, 1821-1992." Journal of Latin American Studies Quincentenary supp.: 99-144.

—. 1994. "Popular Culture and the Revolutionary State in Mexico, 1910-1940." Hispanic American Historical Review 74:393-444.

- . 2002. "The Weight of the State in Modern Mexico." Pp. 212-253 in Studies in the Formation of the Nation-State in Latin America, edited by James Dunkerley. London: Institute of Latin American Studies.

Lieberman, Evan S. 2003. Race and Regionalism in the Politics of Taxation in Brazil and South Africa. Cambridge, UK: Cambridge University Press.

Lomnitz, Claudio. 2000. "Nationalism as Practical System: Benedict Anderson's Theory of Nationalism from the Vantage Point of Spanish America." in The Other Mirror: Grand Theory through the Lens of Latin America, edited by Miguel Angel Centeno and Fernando Lopez-Alves. Princeton: Princeton University Press.

Loveman, Mara. 2005. "The Modern State and the Primitive Accumulation of Symbolic Power." American Journal of Sociology 110:1651-1683.

Mahoney, James, and Dietrich Rueschemeyer (eds.). 2003. Comparative Historical Analysis in the Social Sciences. New York: Cambridge University Press.

Mann, Michael. 1984. "The Autonomous Power of the State: Its Origins, Mechanisms and Results." Archives Europeennes de Sociologie 25:185-213.

- 1993. The Sources of Social Power. Volume 2: The Rise of Classes and Nation States 1760-1914. Cambridge, UK: Cambridge University Press.

Mejía Barquera, Fernando. 1989. La industria de la radio y la televisión y la política del estado mexicano, 1920-1960. Mexico City: Fundación Manuel Buendía.

Meyer, Lorenzo. 1977. "La etapa formativa del Estado mexicano contemporaneo (1928-1940)." Foro Internacional 17:453-476.

—. 2000b. "La institucionalización del nuevo régimen." Pp. 823-880 in Historia general de México, edited by Centro de Estudios Históricos. Mexico City: Colegio de México.

Oszlak, Oscar. 1982. La formación del estado argentino. Buenos Aires: Editorial de Belgrano.

Pérez Montfort, Ricardo. 1994. Estampas del nacionalismo popular mexicano. Mexico City: Centro de Investigaciones y Estudios Superiores en Antropología Social (CIESAS).

Pierson, Paul. 2004. Politics in Time: History, Institutions, and Social Analysis. Princeton: Princeton University Press.

Plotkin, Mariano. 2002. Mañana es San Perón: a Cultural History of Peron's Argentina. Wilmington: Scholarly Resources. 
Rock, David. 1987. Argentina, 1516-1982: From Spanish Colonization to the Falklands War. Berkeley: University of California Press.

-. 2002. State Building and Political Movements in Argentina, 1860-1916. Stanford: Stanford University Press.

Puiggrós, Adriana. 1992. "La educación argentina desde la reforma Saavedra-Lamas hasta el fin de la década infame. Hipótesis para la discusión." in Escuela, democracia y orden (1916-1943), edited by Adriana Puiggrós. Buenos Aires: Galerna.

Raby, David L. 1989. "Ideología y construcción del estado: la función política de la educación rural en México, 1921-1935." Revista Mexicana de Sociología 51: 305-320.

Rivera Castro, José. 1983. En la presidencia de Plutarco Elías Calles, 1924-1928. Vol. 8 of La clase obrera en la historia de México. Mexico City: Siglo Veintiuno.

Romero, Luis Alberto. 2001. Breve historia contemporánea de la Argentina. Buenos Aires: Fondo de Cultura Económica.

Rueschemeyer, Dietrich. 1973. Lawyers and their Society: a Comparative Study of the Legal Profession in Germany and in the United States. Cambridge, MA: Harvard University Press.

-. 1986. Power and the Division of Labour. Stanford: Stanford University Press.

Saítta, Sylvia. 2001. "Entre la cultura y la política: los escritores de izquierda." Pp. 383-428 in Crisis económica, avance del Estado e incertidumbre política (1930-1943), edited by Alejandro Cattaruzza. Buenos Aires: Editorial Sudamericana.

Secretaría de Estado de Cultura y Educación. 1966. "Suplemento estadístico: Enseñanza primaria, años 1940-1964." Buenos Aires.

Sigal, Silvia. 2002a. "Intelectuales y peronismo." Pp. 481-522 in Los años peronistas, edited by Joan Carlos Torre. Buenos Aires: Sudamericana.

Skocpol, Theda. 1979. States and Social Revolutions: A Comparative Analysis of France, Russia, and China. New York: Cambridge University Press.

Smith, Anthony. 1991. National Identity. Reno: University of Nevada Press.

Soifer, Hillel. 2008. "State Infrastructural Power: Conceptualization and Measurement in Empirical Analysis." Studies in Comparative International Development, forthcoming.

Spalding, Hobart. 1972. "Education in Argentina, 1890-1914: The Limits of Oligarchical Reform." Journal of Interdisciplinary History 3:31-61.

Torre, Juan Carlos. 1990. La vieja guardia sindical y Perón. Buenos Aires: Sudamericana.

Vaughan, Mary Kay. 1982. The State, Education, and Social Class in Mexico, 1880-1928. DeKalb: Northern Illinois University Press.

-. 1997. Cultural Politics in Revolution: Teachers, Peasants, and Schools in Mexico, 19301940. Tucson: University of Arizona Press.

vom Hau, Matthias. 2007. "Contested Inclusion: A Comparative Study of Nationalism in Mexico, Argentina, and Peru." Ph.D. Thesis, Brown University, Department of Sociology.

Wilkie, James W. 1970. The Mexican Revolution: Federal Expenditure and Social Change since 1910. Berkeley: University of California Press.

Wuthnow, Robert. 1989. Communities of Discourse. Ideology and Social Structure in the Reformation, the Enlightenment and European Socialism. Cambridge, Harvard University Press. 


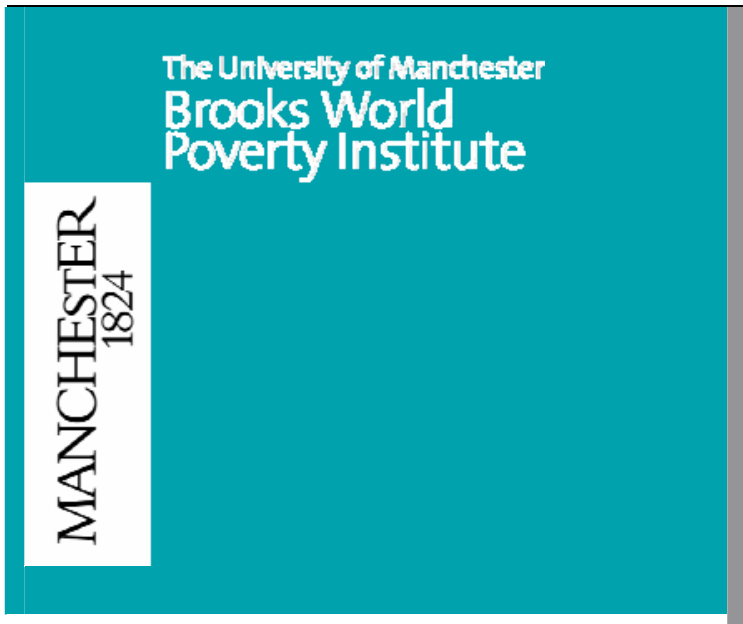

Executive Director

Professor Tony Addison

Research Director

Professor Michael Woolcock

Associate Director

Professor David Hulme

Contact:

Brooks World Poverty Institute

The University of Manchester

Humanities Bridgeford Street

Building

Oxford Road

Manchester

M13 9PL

United Kingdom

Email: bwpi@manchester.ac.uk
The Brooks World Poverty Institute (BWPI)

creates and shares knowledge to help end global poverty.

BWPI is multidisciplinary, researching poverty in both the rich and poor worlds.

Our aim is to better understand why people are poor, what keeps them trapped in poverty and how they can be helped drawing upon the very best international practice in research and policy making.

The Brooks World Poverty Institute is chaired by Nobel Laureate, Professor Joseph E. Stiglitz. 